\title{
ANALISIS BUSINESS PLAN PELAKU UMKM DI KECAMATAN MLARAK
}

\author{
Moh. Zaenal Abidin \\ Institut Agama Islam Negeri Ponorogo \\ Email: abidin07ae@gmail.com
}

\begin{abstract}
Entrepreneurship is an activity to meet the needs of human life. With the existence of entrepreneurship, unemployment can be reduced, considering that in Indonesia the unemployment rate is very high. Especially with the Covid-19 outbreak, the unemployment rate has increased. In starting a business, careful planning is needed, so that the business we run is in accordance with the goals and expectations we want. In addition, the existence of a business plan can make it easier to evaluate the shortcomings of the business that we are running. Therefore business planning lies at the very top before doing or starting a business. The business plan or business plan includes a vision and mission, an overview of the company, marketing, goods and services produced, efforts to increase sales and capital.
\end{abstract}

Keywords: Entrepreneurship, Unemployment, Business Planning

\begin{abstract}
Abstrak: Berwirausaha merupakan kegiatan untuk memenuhi kebutuhan hidup manusia. Dengan adanya kewirausahaan pengangguran dapat berkurang, mengingat di Indonesia tingkat pengangguran yang sangat tinggi. Terlebih dengan adanya wabah covid-19 ini, tingkat pengangguran meningkat. Dalam memulai sebuah usaha maka perlu perencanaan yang matang, agar usaha yang kita jalankan sesuai dengan tujuan dan harapan yang kita inginkan. Selain itu dengan adanya perencanaan usaha dapat mempermudah dalam mengevaluasi kekurangan terhadap usaha yang sedang kita jalankan. Oleh karena itu perencanaan usaha terletak pada posisi paling atas sebelum melakukan atau mengawali sebuah usaha. Dalam business plan atau perencanaan usaha didalamnya mencangkup visi dan misi, gambaran tentang perusahaan, pemasaran, barang dan jasa yang dihasilkan, usaha untuk meningkatkan penjualan dan permodalan.
\end{abstract}

Kata kunci: Berwirausaha, Pengangguran, Perencanaan Usaha

\section{PENDAHULUAN}

Berwirausaha merupakan kegiatan untuk memenuhi kebutuhan hidup manusia. Dengan adanya kewirausahaan pengangguran dapat berkurang, mengingat di Indonesia tingkat pengangguran yang sangat tinggi. Terlebih dengan adanya wabah covid-19 ini, tingkat pengangguran meningkat. Dalam memulai sebuah usaha maka perlu perencanaan yang matang, agar usaha yang kita jalankan sesuai dengan tujuan dan harapan yang kita inginkan. Selain itu dengan adanya perencanaan usaha dapat mempermudah dalam mengevaluasi kekurangan terhadap usaha yang sedang kita jalankan. Oleh karena itu perencanaan usaha terletak pada posisi paling atas sebelum melakukan atau mengawali 
sebuah usaha. Dengan adanya perencanaan usaha kita dapat memberi rancangan kearah mana bisnis yang kita jalankan akan dibawa atau di arahkan.

Dalam business plan atau perencanaan usaha didalamnya mencangkup visi dan misi, gambaran tentang perusahaan, pemasaran, barang dan jasa yang dihasilkan, usaha untuk meningkatkan penjualan dan permodalan. Untuk itu penulis melakukan pengamatan dengan metode research field dan wawancara di WISMA IKPM Gontor dengan alasan ingin mengetahui business plan yang diterapkan, oleh karena itu penulis mengambil judul Analisis business plan pelaku UMKM di kecamatan Mlarak.

\section{TINJAUAN LITERATUR}

Salah satu kunci sukses dalam memulai usaha ialah adanya kemampuan dalam menuangkan ide-ide atau gagasan cemerlang yang kreatif dan inovatif. Ide tersebut harus memiliki nilai ekonomi yang tinggi kemudian dituangkan dalam rencana bisnis yang matang. Dalam rencana bisnis berisi tentang apa saja yang akan dikerjakan dalam suatu bisnis kedepan meliputi alokasi sumber daya, perhatian faktor-faktor kunci dan mengolah permasalahan-permasalahan serta peluang-peluang yang ada. Menurut Munjiati Munawaroh, Kebutuhan tentang suatu perencanaan bisnis menjadi sesuatu yang mutlak apabila kita akan menjalakan suatu bisnis, karena perencanaan bisnis suatu ibarat sebuah kompas atau peta yang akan mengarahkan kita ke tempat tujuan kita(Munawaroh, Rimiyati, \& Hindasah, 2019). Melalui perencanaan yang matang, maka kita dapat menetapkan dan mencapai tujuan dengan mudah.

Menurut Hisrich and Peters, rencana usaha merupukan dokumen yang tertulis oleh wirausaha yang disiapkan untuk menggambarkan semua unsur-unsur yang relevan baik unsur internal maupun eksternal tentang perusahaan untuk memulai sebuah usaha(Suprapto, 2018). Dalam perencanaan tersebut berisi tentang perencanaan pemasaran, permodalan, manufaktur serta sumber daya manusia. Sedangkan menurut Richard L. Daft business plan ialah dokumen yang menjelaskan secara rinci tentang bisnis yang disiapkan oleh seorang wirausahawan sebelum membuka bisnis baru(Daft, 2007). Dengan kata lain calon wirausaha harus menggambarkan seperti apa bisnis yang akan dijalankan, kearah mana bisnis yang akan dijalankan.

Dari pendapat diatas dapat disimpulkan bahwa, rencana usaha Business Plan adalah dokumen tertulis yang harus disiapkan oleh wirausahawan sebelum memulai 
usaha baru, yang berisi tentang gambaran usaha yang akan dijalankan baik dari segi internal maupun eksternal agar dapat berjalan dengan lancar.

Menurut Rhonda Abrams kerangka dasar dari suatu rencana usaha meliputi sebagai berikut(Abrams \& Yuwono, 2008):

a. Ringkasan Eksekutif, yang berisi tentang aspek terpenting dalam bisnis, serta rangkuman poin utama dalam perencanaan bisnis.

b. Deskripsi perusahaan, didalamnya menampilkan tentang seluk beluk diberdirikannya usaha tersebut.

c. Deskripsi target pasar, berisi tentang pendeskripsian tipe orang atau bisnis yang disukai konsumen, serta penjelasan kebutuhan dan keinginan konsumen.

d. Perencanaan pemasaran dan penjualan, di dalamnya menguraikan tentang bagaimana cara untuk menjangkau konsumen dan melakukan penjualan produk.

e. Perencanaan operasional, berisi tentang bagaiman cara menjalankan bisnis, sertas faktor-faktor operasional yang mungkin akan menjadi penghalang.

f. Tim manajemen, yaitu pendeskripsian orang-orang yang terlibat dalam menjalakan bisnis.

g. Rencana pengembangan dan prestasi, berisi tentang perkembangan bisnis dalam waktu tertentu, serta prestasi yang sudah dicapai.

\section{METODE PENELITIAN}

Metode penulisan yang digunakan adalah metode kualitatif dengan pendekatan fenomenologi. Pendekatan fenomenologi berhubungan dengan kehidupan keseharian dan dunia intersubjektif (dunia kehidupan) partisipan. Dimana peneliti mencoba menjelaskan atau mengungkapkan fenomema pengalaman yang didasari pada beberapa kejadian yang terjadi oleh beberapa individu. Menurut Polkinghome (1989) dalam Creswell (2014), pendekatan fenomenologi menggambarkan arti sebuah pengalaman hidup dari beberapa orang tentang sebuah fenomena atau kejadian(Creswell, 2016). Orang-orang yang terlibat dalam menangani sebuah fenomena atau kejadian mengeksplorasi terhadap struktur kesadaran pengalaman hidup manusia. Dalam penelitian ini, penulis langsung ke lapangan guna untuk menggali informasi yang dibutuhkan dalam penulisan artikel ini. Tindakan yang dilakukan penulis meliputi analisa dilapangan serta wawancara dengan pelaku UMKM yang ada di kecamatan Mlarak. 


\section{HASIL DAN PEMBAHASAN}

\section{Pengertian}

Perencanaan usaha atau business plan ialah sebuah rencana yang dibentuk sebelum memulai sebuah usaha, agar usaha yang akan kita jalankan sesuai dengan target yang kita inginkan. Dalam perencanaan usaha tidak terdapat aturan yang baku ataupun sebuah patokan untuk membuat rencana usaha, namun secara umum meliputi : pendahuluan, isi dan penutup.

\section{Tujuan}

Disusunya sebuah perencanaan usaha memiliki tujuan sebagai berikut :

a. Untuk pencapaian target

b. Alat komunikasi terhadap konsumen.

c. Sebagai penambah modal, apabila terdapat investor yang ingin mengivestasikan uangnya untuk kelancaran usaha yang sedang dijalankan.

d. Mempermudah pengawasan.

\section{Kerangka dasar Business plan}

Dalam business plan, terdapat rancangan usaha yang pada dasarnya terdiri atas tiga bagian, yaitu bagian pendahuluan yang mana di dalamnya berisi tentang alasanalasan penyusunan, isi yang memuat aspek-aspek perusahaan yang akan di rancang, dan penutup yang berisi pelajaran-pelajaran penting yang diperoleh selama proses pembelajaran ini(Rusdiana, 2014).

Dalah hal ini penulis melakukan wawancara dengan salah satu karyawan pada sebuah BMT di daerah Mlarak. Disana pada halaman pertama tertera nama-nama yang bisa dihubungi sewaktu-waktu, yang kemudian dilanjutkan dengan visi-misi, latar belakang pendirian BMT tersebut, serta sejarah pendiriannya. Selain itu, saya juga membandingkan dengan usaha jasa yang dalam pondok modern Darussalam Gontor berupa penginapan, dan disitu tertera visi dan misi akan usaha tersebut.

Pada hakikatnya di dalam busines plan tidak ada aturan-aturan yang baku, akan tetapi menurut Buchori Alma pada umumnya business plan mencangkup hal-hal sebagai berikut(Alma, 2006): 
1. Halaman depan

Pada umumnya dicantumkan nama perusahaan, alamat perusahaan, nama orang yang bertanggung jawab dan dapat dihubungi sewaktu-waktu melalui telepon. Dilakukan untuk mencari orang yang bertanggung jawab dalam business plan. Seperti contoh dalam usaha penginapan yang saya teliti ialah nomor staf penginapan atau pun manejer nya.

2. Daftar isi

Seperti pada umumnya daftar isi, di dalamnya harus terperinci dengan nomor-nomor halamannya yang sesuai dengan urutan yang akan disusunnya.

3. Ringkasan eksekutif

Dalam ringkasan eksekutif ini berisi tentang penjelasan secara singkat tentang business plan secara komplit dan menarik peminat pembaca. selain itu harus kita ingat, namanya ringkasan itu harus singkat, sekitar 1-2 halaman saja.

4. Penjelasan tentang perusahaan

Disini diungkapkan atau diisi tentang strategi perusahaan dan tim manajemen yang mengelola perusahaan, agar banyak yang berminat dengan bisnis yang akan kita jalankan. Sebagai contoh dapat dicantumkan berupa fasilitas suatu jasa serta tariff terhadap jasa tersebut, dengan begitu para calon konsumen dapat menimbang apaapa yang mereka dapatkan terhadap suatu perusahaan jasa tersebut.

5. Pemasaran

Dalam pemasaran, diungkapkan seberapa besar potensi pasar yang akan dituju, serta ramalan berapa jumlah target konsumen yang akan ditempuh di beberapa tahun kedepan. Dalam usaha yang saya teliti ini tujuan atau sasarannya ialah para wali santri yang ada dalam pondok modern Darussalam Gontor, sehingga jumlah target yang ditetapkan lumayan memenuhi ataupun melebihi targetnya.

6. Barang dan jasa yang dihasilkan

Dalam aturan ini ditulis mengenai kualitas, kuantitas, kegunaan, manfaat, dan keistimewaan barang dan jasa yang ditawarkan oleh sebuah perusahaan. Keistimewaan dalam usaha jasa ini yaitu berupa tempat penginapan yang nyaman dan tidak terlalu jauh dari keramaian jalan raya, sehingga banyak para konsumen yang menikmatinya. Disisi lain apabila ingin mengadakan acara semisal seminar atau yang lain sebagainya dalam usaha jasa yang saya teliti ini menyiapkan dan menerima 
bookingan secara full dengan fasilitas yang lengkap seperti makan prasmanan sehari tiga kali, tempat parkiran yang luas dan lain sebagainya.

7. Usaha meningkatkan penjualan

Disini dijelaskan tentang strategi-strategi promosi yang akan digunakan untuk meningkatkan penjualan, baik dengan cara membuka cabang-cabang di berbagai daerah ataupun tenaga penjualan barang. Selain di desa Gontor, usaha jasa ini juga sudah membuka cabang di berbagai daerah guna memperluas wilayah dan pendapatan.

8. Permodalan

Dalam permodalan ini diisi tentang rencana permodalan dan proyeksi permodalan, neraca pendahuluan, aliran kas dan pendapatanya. Permodalan yang diperoleh yaitu dari pondok pusat, yang mana uang hasil dari usaha tersebut kemudian di laporkan kepada bagian bendahara pondok, dan selanjutnya digunakan untuk pembangunan ataupun kebutuhan yang dibutuhkan dalam pondok tersebut.

9. Apendiks

Di dalam apendiks ini dicantumkan beberapa hal-hal yang penting untuk melengkapi sebuah business plan, misalnya akte perusahaan, SIUP (Surat Izin Usaha Perdagangan).

\section{KESIMPULAN}

Perencanaan usaha atau business plan ialah sebuah rencana yang dibentuk sebelum memulai sebuah usaha, agar usaha yang akan kita jalankan sesuai dengan target yang kita ingin kan. Tujuan business plan antara lain untuk pencapaian target, alat komunikasi terhadap konsumen, penambah modal, dan mempermudah pengawasan. Bentuk formal bussines plan adalah halaman depan, daftar isi, ringkasan eksekutif, penjelasan tentang perusahaan, pemasaran, produk yang dihasilkan, usaha peningkatan penjualan, permodalan dan appendiks.

\section{REFRENSI}

Abrams, R., \& Yuwono, V. A. (2008). Business Plan In a Day: Cara Jitu Membuat Rencana Bisnis (Terjemah oleh Vivin Andhika Yuwono). Yogyakarta: Kanisius. Alma, B. (2006). Kewirausahaan. Bandung: Alfabeta.

Creswell, J. W. (2016). Research Design: Pendekatan Metode Kualitatif, Kuantitatif, dan Campuran (Edisi 4). Yogyakarta: Pustaka Pelajar. 
Daft, R. L. (2007). ORGANIZATION THEORY AND Design INSTRUCTOR'S 9TH EDITION (9th Edition). Mason, OH: THOMSON.

Munawaroh, M., Rimiyati, H., \& Hindasah, L. (2019). PERENCANAAN BISNIS Untuk Program Strata 1. Yogyakarta: LP3M UMY.

Rusdiana, A. (2014). Kewirausahaan: Teori dan Praktek. Bandung: Pustaka Setia.

Suprapto, H. A. (2018). Pelatihan pembuatan proposal rencana bisnis (business plan) bagi siswa madrasah Tsanawiyah Nurul Hikmah dan SMP Al-ihsan guna meningkatkan kemampuan berwirausaha. Abdimas Siliwangi, 1(2), 81-88. 